\title{
OSEMDESET LET PROF. DR. MATJAŽA JERŠIČA
}

Leta 1976 je bil v nemški reviji Materialien, ki je izhajala v Frankfurtu, objavljen prvi pregled dela slovenskih geografov na področju geografije turizma, katerega avtor je bil dr. Matjaž Jeršič. V prispevku je navedel le štiri dela, med katerimi sta bili dve njegovi. Pri tem ni šlo za veliko selektivnost pri navajanju virov, temveč predvsem za posledico precejšnjega zanemarjanja tega področja s strani slovenske geografije v predhodnem obdobju. Kljub temu, da je takrat turizem že postal pomemben sestavni del življenja slovenskega prebivalstva, mu

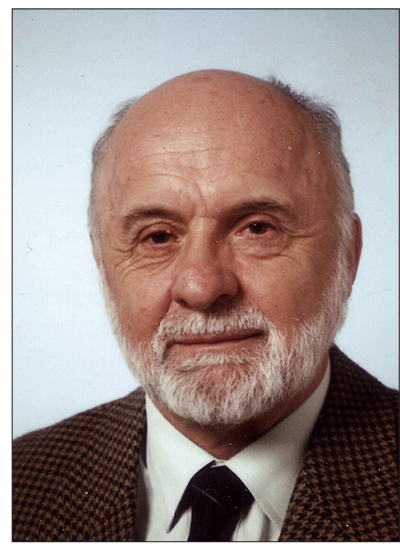
je pred tem geografija namenjala razmeroma malo pozornosti. Danes je - v veliki meri ravno po njegovi zaslugi - situacija bistveno drugačna. Dr. Matjaž Jeršič, ki je letos praznoval svojo osemdesetletnico, je bil prvi slovenski geograf, ki se je s tem področjem začel intenzivno ukvarjati in se že v sedemdesetih letih uveljavil kot vodilni strokovnjak na področju geografije turizma ne le v Sloveniji, ampak tudi v takratni Jugoslaviji. Njegovo strokovno in raziskovalno delo pa ni bilo nikoli omejeno zgolj na preučevanje turizma in rekreacije, čeprav jima je namenil največ pozornosti. Na svoji dolgi in bogati poklicni poti se je namreč ukvarjal s številnimi strokovnimi področji, ki jim je vtisnil pomemben pečat.

Dr. Mirko Pak je leta 1994 v Geografskem vestniku temeljito predstavil vsebinsko bogato in plodno strokovno pot prof. Matjaža Jeršiča. Na tem mestu bi kazalo omeniti le nekatere pomembnejše mejnike in dosežke.

Diplomiral je leta 1960 in se dve leti kasneje (1962) zaposlil na Inštitutu za geografijo Univerze v Ljubljani. Leta 1965 je uspešno zagovarjal doktorsko disertacijo z naslovom Družbena geografija Blejskega kota. Že v šestdesetih letih je bil nosilec več raziskovalnih nalog, ki so obravnavale različne tematike (npr. izletniška potovanja, turizem na kmetiji, vrednotenje prostora $\mathrm{z}$ vidika turizma in rekreacije). Večkrat se je tudi strokovno izpopolnjeval v tujini.

Zelo pomemben sklop njegovega strokovnega delovanja je sodil na področje prostorskega planiranja. Leta 1970 se je vključil v delo, povezano s pripravo strokovnih podlag za prostorski plan SR Slovenije, in se pozneje zaposlil na takratnem Biroju za regionalno prostorsko planiranje. Rezultati njegovega kasnejšega dela na področju priprav za dolgoročno usmerjanje uporabe slovenskega prostora so vidni v publikacijah Zavoda SR za družbeno planiranje z naslovom Zasnova uporabe prostora SR Slovenije. Sodeloval je tudi pri več drugih nalogah s tega področja.

Posebej kaže omeniti njegovo dolgoletno pedagoško delo, s katerim je začel leta 1974 kot vabljeni predavatelj na Fakulteti za arhitekturo, gradbeništvo in geodezijo. Leta 1982 se je zaposlil na Filozofski fakulteti ljubljanske univerze, kasneje pa je predaval še na več drugih fakultetah. Poleg predavanj pri več predmetih (npr. Geo- 
grafija turizma, Geografija prometa, Geografija razvitih držav, Metodologija socialne geografije, usmeritveni predmet Turistična geografija idr.) je treba posebej omeniti, da je bil mentor veliki množici študentov. Tako je bil mentor pri 76 diplomskih delih, 8 magistrskih nalogah in 3 doktorskih disertacijah. Največ jih je sodilo na področje geografije turizma in rekreacije. Tudi s tem je utrdil temelje preučevanja tega vsebinskega področja v okviru slovenske geografije.

Pomemben segment njegovega dela je bila priprava učbenikov (npr. Turistična geografija iz 1. 1985, Osnove turizma iz 1. 1990), omeniti pa je treba tudi njegovo sodelovanje pri pripravi turističnega vodnika Slovenija, ki je doživel številne ponatise, ter različnih geografskih monografskih publikacij (npr. Geografski atlas Slovenije, Geografija Slovenije).

Dr. Matjaž Jeršič se je kot prvi slovenski geograf lotil obravnavanja številnih tem, ki so se kasneje izkazale kot zelo relevantne in so vzbudile tudi pozornost drugih strokovnjakov. Med temi vsebinami lahko omenimo izletniško (bližnjo) rekreacijo, vrednotenje prostora za rekreacijo, problematiko počitniških bivališč, slovenskih zimskošportnih turističnih središč idr. Tako je v svojih delih podal prvo celovito podobo izletniške oziroma bližnje rekreacije v Sloveniji, ki je do danes ostala tudi najbolj podrobna. To tematiko je obravnaval v številnih člankih, pa tudi monografski publikaciji Bližnja rekreacija prebivalcev Slovenije iz leta 1998. Njegovo delo Sekundarna počitniška bivališča v Sloveniji in zahodni Istri iz leta 1968 je bilo prvo slovensko geografsko delo, ki je bolj temeljito obravnavalo pojav počitniških bivališč, k tej tematiki pa se je kasneje še večkrat vračal. Kontinuirano in $\mathrm{z}$ različnih zornih kotov je $\mathrm{v}$ številnih delih obravnaval tudi turizem v slovenskih Alpah kot eni najbolj privlačnih slovenskih pokrajin. Že zgodaj je opozarjal na dileme in probleme, kot so npr. odnosi med turizmom in okoljem, problemi zanesljivosti snežne odeje, konflikti rekreacije z drugimi dejavnostmi idr. Pomembna kakovost njegovih del je njihova praktična oziroma aplikativna relevantnost, ki se je med drugim kazala v njihovi navezanosti na problematiko prostorskega planiranja. Rezultate svojega strokovnega dela je objavil v vrsti člankov in monografskih publikacij. Veliko svojih prispevkov je objavil tudi na tujem, zlasti na nemškem govornem področju.

Brez prispevka Matjaža Jeršiča slovenska geografija ne bi bila enaka, kar še posebej velja za področje geografije turizma in rekreacije. Njegovo več kot štiridesetletno strokovno delo je pustilo trajno sled na področju geografije in ostaja še kako relevantno tudi danes.

\section{Dejan Cigale}

